\title{
Comparison of Pyrolytic Products from Flue-Cured Tobacco Leaf and a Reconstituted Tobacco Sheet*
}

\author{
by W. S. Schlotzhauer and O. T. Chortyk \\ Richard B. Russell Agricultural Research Center, Agricultural Research Service, \\ United States Department of Agriculture, Athens, Georgia, USA
}

During the past decade the use of various reconstituted tobacco sheet types in the manufacture of commercial smoking products has increased greatly. Because of these technological changes, the tobacco researcher has sought to determine possible alterations in smoke composition which may have a significant effect on physiological and biological properties of smoke. Wynder and Hoffmann (1) first reported reduced tumorigenicity in reconstituted tobacco sheet smoke condensates. Subsequent studies $(2,3)$ have confirmed this initial report, noting, in some cases, $60 \%$ reduction of tar tumorigenicity of sheet cigarettes in comparison to control cigarettes. Moreover, significant differences have been determined for biological activity of condensates prepared from cigarettes consisting solely of leaf stem and main veins when compared to cigarettes manufactured from leaf lamina alone $(4,5)$. These latter observations are of particular significance, since stems and veins have been incorporated in sheet manufacture to a large degree. Thus, for example, blend specifications for the Kentudky Reference cigarette, based on disappearance figures for the years 1962 to 1966 , include $14.2 \%$ of flue-cured stems (6). It is reasonably inferred that such values for stem incorporation have increased in recent years.

Comparative studies of smoke composition of various sheet, stem, and blended cigarettes have generally reported levels of total particulate matter and selected individual components. Klimisch (7) observed lower levels of condensate fractions, containing aliphatic and aromatic hydrocarbons, and lower amounts of nicotine and phenol in sheet smoke condensates versus control cigarette condensate. Halter and Ito (3) reported lower tar, benzo(a)pyrene (BaP), nicotine, and phenol levels in condensates of sheet with additives such as $\mathrm{KNO}_{3}$ and postulated that the altered burning process affects the formation of mainstream smoke. Similar differences in tar, total polynuclear aromatic hydrocarbons (PAH), and volatile phenols were reported by Hoffmann and Wynder (5) in studies on stem cigarette condensates.

Another factor which affects smoke composition in reconstituted sheet cigarettes versus control cigarettes is processing technology (solvents used, high or low temperature treatments, product thickness, etc.). These

- Received for publication: 17th September, 1974. factors apparently alter burning properties to produce a change in ratio of mainstream and sidestream components $(2,3,8)$. Relations of biological activity of condensates to $\mathrm{BaP}$ levels were not readily apparent in several of these studies. Chouroulinkov et al. (4) showed no significant differences in BaP content of stem and lamina condensates while Dontenwill et al. (2), in comparing tumorigenicity of condensates from sheet of five different processing types, found no apparent correlation with BaP content, but suggested that total PAH levels might be a factor.

These observations suggested to us that a more detailed survey of individual constituents formed by thermal degradation of sheet, stem, and leaf would prove of value. Accordingly, in this report we present analytical data on products of pyrolysis of whole flue-cured tobacco leaf, flue-cured stems, and a representative commercial tobacco sheet. Values are included for total condensable products, various pyrolyzate fractions of biological interest, nicotine, individual phenols, carboxylic acids, and PAH. Subsequent studies will deal with vapor phase constituents.

\section{MATERIALS AND METHODS}

\section{Materials Pyrolyzed for Comparative Purposes}

Whole flue-cured leaves, obtained from a 1969 Old Belt crop, were used for pyrolysis. Stems were recovered from leaves of the same crop. The reconstituted tobacco sheet was prepared by a commercial paper process from a different crop of flue-cured tobacco. It consisted essentially of fines, stems, and midribs, with a much greater percentage of stems and midribs than occurs in the whole leaf. Samples were ground to 32 mesh (Wiley Mill) to provide increased homogeneity for comparative purposes and humidified over $76 \%$ glycerol $/ \mathrm{H}_{2} \mathrm{O}$ for $4^{8}$ hours, prior to pyrolysis.

\section{Pyrolytic Methods and Analysis of Pyrolyzates}

Pyrolyses were performed in horizontal Vycor tubes, using apparatus previously described (g). Samples were positioned in the center of the pyrolysis tube at ambient temperature in a nitrogen atmosphere and brought to $940^{\circ} \mathrm{C}$ by raising oven temperature at $10^{\circ} \mathrm{C} / \mathrm{min}$. 
Figure 1. Fractionation and analysis of pyrolysis products.

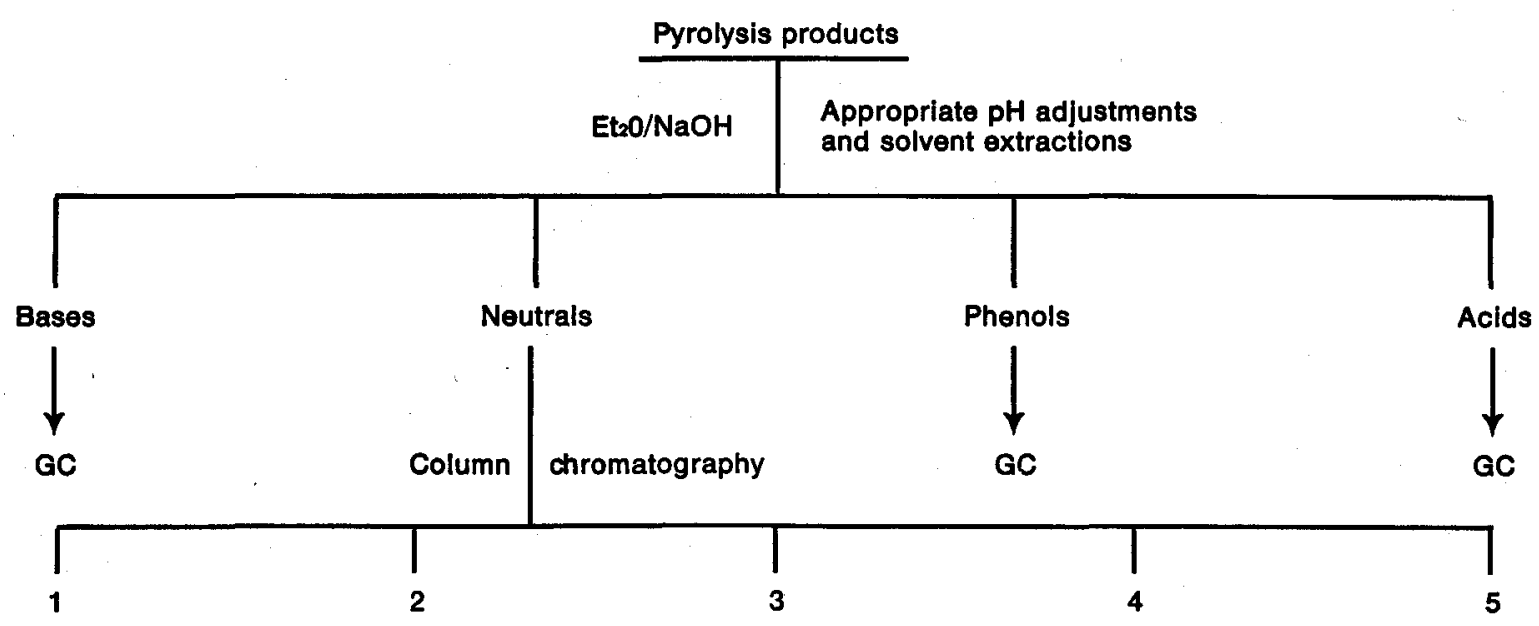

Petroleum ether

$25 \%$ Benzene/ petroleum ether (PAH)

Pyrolysis products were condensed in dry ice/acetone cooled traps, dissolved in diethyl ether-aqueous sodium hydroxide, and fractionated into bases, neutrals, phenolics, and acids by appropriate $\mathrm{pH}$ adjustments and ether extractions (Fig. 1). Neutral components $(0.5$ to $1.5 \mathrm{~g}$ ) were further subfractionated following the general chromatographic procedure of Bock et al. (10). Solvents used were nanograde, distilled in glass. Thus, $1 \mathrm{~g}$ of total neutrals was chromatographed on $100 \mathrm{~g}$ acid-washed, activated silicic acid and $500 \mathrm{ml}$ fractions (petroleum ether, $25 \%$ benzene in petroleum ether, and benzene) or $250 \mathrm{ml}$ fractions (ethyl ether and methyl alcohol) were collected.

Gas chromatographic (GC) analyses were performed on a Varian* Model 2100 instrument with dual flame ionization detectors under the following conditions:

a) Nicotine analyses: Column: $6^{\prime} X_{1} / 8^{\prime \prime}$ glass, $10 \%$ Carbowax $20 \mathrm{M} / 2 \% \mathrm{KOH}$ on $80 / 100$ mesh Chromosorb W/AW; detector temperature, $200^{\circ} \mathrm{C}$; injector temperature, $200^{\circ} \mathrm{C}$; column temperature, $140^{\circ} \mathrm{C}$; helium flow rate, $32 \mathrm{ml} / \mathrm{min}$.

b) Phenol analyses: Column: $6^{\prime} \times_{1} / 8^{\prime \prime}$ glass, $10 \%$ SP 2401 on 100/120 mesh Supelcoport; detector temperature, $225^{\circ} \mathrm{C}$; injector temperature, $225^{\circ} \mathrm{C}$; column temperature, $40^{\circ} \mathrm{C}$ for $3 \mathrm{~min}$, programmed to $200^{\circ} \mathrm{C}$ at $4 \% \mathrm{~min}$; helium flow rate, $32 \mathrm{ml} / \mathrm{min}$.

c) Acid analyses: Column: $6^{\prime} \times_{1} / 8^{\prime \prime}$ glass, 10\% SP $1200 / 1 \% \mathrm{H}_{3} \mathrm{PO}_{4}$ on $80 / 100$ mesh Chromosorb W/AW; detector temperature, $180^{\circ} \mathrm{C}$; injector temperature, $180^{\circ} \mathrm{C}$; column temperature, $40^{\circ} \mathrm{C}$ for $3 \mathrm{~min}$, programmed to $140^{\circ} \mathrm{C}$; helium flow rate, $32 \mathrm{ml} / \mathrm{min}$.

\footnotetext{
- Mention of trade or company names does not imply endorsement by the Department over others not named.
}

d) $P A H$ analyses: Column: $6^{\prime} \times 1 / 8^{\prime \prime}$. glass, $5 \%$ Dexsil 300 GC on $80 / 100$ mesh Chromosorb W; detector temperature, $325^{\circ} \mathrm{C}$; injector temperature, $275^{\circ} \mathrm{C}$; column temperature, $70^{\circ} \mathrm{C}$ for $3 \mathrm{~min}$, programmed to $292^{\circ} \mathrm{C}$ at $6^{\circ} / \mathrm{min}$; helium flow rate, $32 \mathrm{ml} / \mathrm{min}$.

Individual components were identified initially by cochromatography with authentic compounds; peak effluents were subsequently collected and identified by UV and/or IR spectroscopy where practicable. Products were quantitated with an Infotronics Model CRS-204 automatic digital integrator.

\section{RESULTS AND DISCUSSION}

To provide background data on the relative chemical compositions of flue-cured leaf and the commercial reconstituted tobacco sheet sample, these materials were extracted successively with petroleum ether, acetone, methyl alcohol (Soxhlet) and with cold, distilled water. Extract yields are presented in Table 1. In comparison with whole leaf, the sheet was significantly deficient in components extractable with nonpolar solvents (waxes, steroids, terpenes, fatty acids and esters, etc.), consisting largely of water-extractable carbohydrates and non-extractable cellular materials, which form the bulk of tobacco stem and midrib. Based on previous data from this laboratory $(11,12)$, one might predict significant alterations in levels of

Table 1. Solvent extraction of flue-cured leaf and reconstltuted tobacco sheet.

\begin{tabular}{l|c|c}
\hline Extracting & \multicolumn{2}{|c}{$\%$ Extract* } \\
\cline { 2 - 3 } solvents & Leaf & Sheet \\
\hline Petroleum ether & 6.14 & 1.06 \\
Acetone & 8.10 & 4.94 \\
Methyl alcohol & 28.41 & 15.40 \\
Water & 32.69 & 29.30 \\
Residue & 24.64 & 48.69 \\
\hline
\end{tabular}

* Based on dry weight of starting material. 
Table 2. Pyrolyzate fractlons from leaf, stem, and sheet.

\begin{tabular}{l|c|c|c|c|c|c}
\hline \multirow{2}{*}{ Fraction } & \multicolumn{3}{|c|}{ Fraction yleids $(\%)^{\star}$} & \multicolumn{3}{c}{ Relative yields } \\
\cline { 2 - 7 } & Leaf & Stem & Sheet & Leaf & Stem & Sheet \\
\hline Neutrals & 8.82 & 6.32 & 4.04 & 100 & 71 & 46 \\
Bases & 2.06 & 0.95 & 0.68 & 100 & 46 & 33 \\
Phenolics & 2.23 & 1.01 & 1.35 & 100 & 45 & 60 \\
Acidics & 0.45 & 0.42 & 0.36 & 100 & 93 & 80 \\
\hline
\end{tabular}

* Based on dry welght of material pyrolyzed.

$\mathrm{PAH}$ in smoke or pyrolysis products, as these compounds have been shown to arise largely from the petroleum ether and acetone-extractable constituents. The effect of sheet composition on pyrolytic production of volatile phenols cannot be so readily predicted. Phenolic smoke constituents have been shown to arise from alcohol-extractable leaf components, which are lower in sheet, and from carbohydrate material, which together represent a considerable percentage of sheet.

Pyrolysis of leaf and sheet, under identical conditions, yields total condensable (dry ice/acetone) pyrolyzates of $20.02 \%$ and $10.01 \%$, respectively, a "tar" level for sheet only half that of leaf. Leaf yielded a slightly lower $(28.36 \%$ versus $33.60 \%)$ residue of inorganic ash, but sheet generated more non-condensable "vapor phase" components $(56.38 \%$ versus $51.63 \%)$.

In a subsequent experiment, leaf, stem, and sheet were each pyrolyzed and the resulting pyrolyzates fractionated (Fig. 1) into various classes of components (Table 2). With the exception of the carboxylic acids, stem and sheet pyrolyzates yield significantly lower amounts of all fractions analyzed. Reduction of neutrals and bases was more dramatic in sheet pyrolyzate, whereas sheet yielded somewhat higher levels of phenolics than stem material. The complex nature of the neutral fractions suggested the need for additional separation. For the neutral portion of cigarette smoke condensate (CSC), Bock et al. (10) had demonstrated significant tumorigenic activity in the $25 \%$ benzene/petroleum ether subfraction (which should contain essentially all $\mathrm{BaP}$ ) and in the polar methyl alcohol fraction, with lesser activity in the benzene eluate. Accordingly, a modified version of the columnchromatographic technique of Bock et al. (10) was used to subfractionate the pyrolysis neutrals. Silicic acid chromatography of the neutral fraction yielded recoveries of $90-96 \%$ in 5 subfractions (Table 3). Sheet and stem pyrolysis yielded significantly less of subfractions 2 und 5 (corresponding to the active subfractions of CSC neutrals) than leaf. Yields of the $25 \%$ benzene/petroleum ether fraction, relative to leaf, were $17 \%$ for sheet and $29 \%$ for stems, and those of the polar methyl alcohol eluates were $69 \%$ for sheet and $79 \%$ for stems. These results further confirm the importance of the petroleum ether extractables of tobacco leaf $(11,12)$ as precursors of PAH. Apparently, the relatively low levels of non-polar materials in sheet resulted in a low yield of the $25 \%$ benzene/petroleum ether subfraction on pyrolysis. The fact that the other active subfraction, the polar methyl alcohol eluate, was not drastically lower in stem and sheet as compared to leaf indicates that precursor materials for this fraction are still relatively intact in sheet, are probably carbohydrate in nature, or bound to a carbohydrate structure.

Yields of individual components of the pyrolyzates of flue-cured leaf and reconstituted tobacco sheet are presented in Tables 4 and 5 . The data show marked variations in quantitative recoveries of selected pyrolyzate constituents from flue-cured leaf and reconstituted sheet. The much lower level of nicotine in sheet pyrolyzate was not unexpected as the relatively low concentration of alkaloids in midribs has long been noted (13). Muranaga et al. (14) reported that total alkaloid content in midribs was $21 \%$ of that of lamina. Generally, the amounts of polynuclear aromatic hydrocarbons in sheet pyrolyzate corresponded to the lowered yield of total neutrals, compared to leaf pyrolysis, i.e. about $50 \%$. Lower levels of PAH reflect the relative absence of lipid components in midrib, utilized in sheet manufacture. As previously noted, the reduction of the active, neutral, PAH-containing subfraction for sheet was greater $(83 \%)$ than any of the individual $\mathrm{PAH}$ (containing from 2 to 5 rings), including BaP. This fact indicated that a considerable portion of pyrolyzate or smoke condensate fractions of biological interest remains to be characterized. Analysis of the volatile phenols demonstrated: (a) unsubstituted phenol was substantially lower and $\mathrm{m} / \mathrm{p}$-cresol somewhat lower in sheet pyrolyzate versus leaf pyrolyzate, and (b) levels of other alkylated phenols, especially xylenols were markedly higher in sheet pyrolyzates. GC-volatile phenols for sheet were $64 \%$ of those for leaf, which is comparable with the $60 \%$ value for total phenolics for sheet pyrolysis, as compared to leaf (Table 2).

Table 3. Subfractions of neutrals trom leaf, stem, and sheet pyrolyzates.

\begin{tabular}{|c|c|c|c|c|c|c|c|}
\hline \multirow{2}{*}{ Subfractions } & \multirow{2}{*}{$\begin{array}{l}\text { Eluting } \\
\text { solvent(s) }\end{array}$} & \multicolumn{3}{|c|}{ Subfraction yields $(\%)$} & \multicolumn{3}{|c|}{ Relative yields } \\
\hline & & Leaf & Stem & Sheet & Leaf & Stem & Sheet \\
\hline 1 & Petroleum ether & 1.55 & 0.27 & 0.27 & 100 & 17 & 17 \\
\hline 2 & $25 \%$ Benzene/petroleum ether & 2.27 & 0.66 & 0.40 & 100 & 29 & 17 \\
\hline 3 & Benzene & 0.85 & 0.52 & 0.38 & 100 & 61 & 45 \\
\hline 4 & Diethyl ether & 3.19 & 4.13 & 2.44 & 100 & 129 & 76 \\
\hline 5 & Methyl alcóhol & 0.94 & 0.74 & 0.56 & 100 & 79 & 69 \\
\hline \multicolumn{2}{|c|}{ Total neutrals } & 8.80 & 6.32 & 4.05 & 100 & 71 & 46 \\
\hline
\end{tabular}


Table 4. Major products of pyrolysis of flue-cured leaf and reconstituted tobacco sheet.

\begin{tabular}{|c|c|c|c|c|}
\hline \multirow{2}{*}{ Component } & \multicolumn{2}{|c|}{$\begin{array}{c}\text { Yleld } \\
(\mathrm{g} / 100 \mathrm{~g} \text { pyrolyzed) }\end{array}$} & \multicolumn{2}{|c|}{ Relative yield } \\
\hline & $\begin{array}{l}\text { Flue- } \\
\text { cured } \\
\text { leaf }\end{array}$ & $\begin{array}{l}\text { Recon- } \\
\text { stituted } \\
\text { sheet }\end{array}$ & Leaf & Sheet \\
\hline Nicotine & $0.720 \mathrm{~d}$ & 0.140 & 100 & 19 \\
\hline \multicolumn{5}{|l|}{ PAHa } \\
\hline Naphthalene & 0.184 & 0.153 & 100 & 83 \\
\hline Alkyl naphthalenes & 0.036 & 0.024 & 100 & 67 \\
\hline Acenaphthylene & 0.068 & 0.031 & 100 & 46 \\
\hline Fluorene & 0.019 & 0.009 & 100 & 47 \\
\hline $\begin{array}{l}\text { Phenanthrene- } \\
\text { anthraceneb, c }\end{array}$ & 0.076 & 0.033 & 100 & 44 \\
\hline Fluoranthene & 0.018 & 0.008 & 100 & 44 \\
\hline Chrysene & 0.019 & 0.008 & 100 & 42 \\
\hline Pyrene & 0.010 & 0.018 & 100 & 180 \\
\hline Benzo(a)pyrene & 0.004 & 0.002 & 100 & 50 \\
\hline Unidentified & 0.039 & 0.020 & 100 & 51 \\
\hline Totale & 0.473 & 0.306 & 100 & 65 \\
\hline \multicolumn{5}{|l|}{ Phenolsa } \\
\hline Phenol & 0.306 & 0.076 & 100 & 25 \\
\hline o-Cresol & 0.043 & 0.042 & 100 & 97 \\
\hline m-Cresol/p-cresolc & 0.069 & 0.039 & 100 & 57 \\
\hline 2,6-Xylenol & 0.026 & 0.059 & 100 & 226 \\
\hline o-Ethylphenol & trace & 0.011 & 100 & 一 \\
\hline 2,5-Xylenol & 0.014 & 0.028 & 100 & 200 \\
\hline p-Ethylphenol & 0.033 & 0.046 & 100 & 139 \\
\hline 3,4-Xylenol & absent & 0.018 & 100 & 一 \\
\hline Unidentified & 0.038 & 0.017 & 100 & 45 \\
\hline Totale & 0.529 & 0.337 & 100 & 64 \\
\hline
\end{tabular}

a In order of GLC retention time.

b Uitraviolet spectra Indicated predominately phenanthrene.'

CNot resolvable under GLC conditions used.

dYields were calculated from the response data of authentic standards. (Response of unidentlfied components estimated by response value of known component closest in retention time.)

${ }^{\mathrm{B}}$ Based on GLC volatile components.

Alterations in phenol content of tobacco smoke could cause important changes in organoleptic and physiological properties of such smoke.

Carboxylic acids were formed in much lower yields than neutrals or phenols, probably because they are readily decarboxylated on pyrolysis. GC-volatile carboxylic acids for sheet amounted to $71 \%$ of the value for leaf, again in good agreement with the $80 \%$ value for total acids for sheet pyrolysis, as compared to leaf (Table 2). Slight differences in volatile fatty acid content of smoke are known to affect organoleptic properties significantly (15).

Except for increased yields of some phenolics and acids, reconstituted tobacco sheet and stems had lower yields of all pyrolysis fractions than flue-cured leaf. Yields of chromatographic fractions, corresponding to CSC biologically active fractions, were substantially lower in sheet than in leaf. Consequently, the continued use of sheet in tobacco products appears warranted.
Table 5. Carboxylle acids from pyrolysls of nue-cured leaf and reconstituted tobacco sheet.

\begin{tabular}{|c|c|c|c|c|}
\hline \multirow[b]{2}{*}{ Componenta } & \multicolumn{2}{|c|}{$\begin{array}{c}\text { Yield } \\
(\mu \mathrm{g} / \mathrm{g} \text { pyrolyzed) }\end{array}$} & \multicolumn{2}{|c|}{ Relative yield } \\
\hline & $\begin{array}{l}\text { Flue- } \\
\text { cured } \\
\text { leaf }\end{array}$ & $\begin{array}{l}\text { Recon- } \\
\text { stituted } \\
\text { sheet }\end{array}$ & Leaf & Sheet \\
\hline Formic/acetiob & 163 & 119 & 100 & 73 \\
\hline Propionic & 90 & 52 & 100 & 58 \\
\hline Iso-butyric & 17 & 7 & 100 & 42 \\
\hline Butyric & 13 & 10 & 100 & 77 \\
\hline Iso-valeric & 7 & - & 100 & - \\
\hline Valeric & 27 & 28 & 100 & 103 \\
\hline Ethylbutyric & 12 & 7 & 100 & 59 \\
\hline Caproic & 12 & 22 & 100 & 183 \\
\hline Unidentified & 59 & 39 & 100 & 67 \\
\hline Total & 400 & 284 & 100 & 71 \\
\hline
\end{tabular}

a In order of GLC retention time.

${ }^{b}$ Not resolvable under GLC conditions used.

\section{CONCLUSION AND SUMMARY}

Pyrolytic products of commercial tobacco sheet, fluecured tobacco leaf, and stems were compared. The yields of acids, bases, neutrals, and phenolics were determined. The neutrals were further characterized by chromatography in order to examine pyrolysis fractions corresponding to biologically active cigarette smoke fractions. Individual phenols, carboxylic acids, polynuclear aromatic hydrocarbons (PAH), and nicotine were determined for sheet and leaf pyrolyzate. Analyses of constituents of various pyrolyzate fractions indicated significantly lower amounts of phenols; PAH, and nicotine in sheet and stem pyrolyzates than in leaf pyrolyzates.

\section{ZUSAMMENFASSUNG}

Diese Arbeit berichtet über den Vergleich der Pyrolyseprodukte von handelsüblichen Tabakfolien, von "fluecured"-Tabakblattgut und von Tabakrippen. Die Ausbeuten an Säuren, Basen, Neutralstoffen und an Phenolen wurden bestimmt. Die Neutralstoffe wurden darüber hinaus durch Chromatographie näher bestimmt, um Pyrolysefraktionen zu untersuchen, die den biologisch aktiven Fraktionen des Cigarettenrauches entsprechen. In den Pyrolyseprodukten der Folien und des Blattgutes wurden außerdem die einzelnen Phenole, die Carbonsäuren, die polycyclischen aromatischen Kohlenwasserstoffe (PAH) und das Nikotin bestimmt. Die Untersuchung der Inhaltsstoffe verschiedener Fraktionen der Pyrolyseprodukte ergab, daß in den Pyrolyseprodukten der Folien und Rippen eine signifikant niedrigere Menge an Phenolen, an polycyclischen aromatischen Kohlenwasserstoffen und an Nikotin enthalten ist als in den Pyrolyseprodukten des Blattgutes. 


\section{RESUME}

On a comparé les pyrolysats de produits commerciaux en tabac reconstitué à ceux des feuilles et des côtes de tabac «flue-cured». On a déterminé les rendements en acides, bases, substances neutres et phénoliques. Les substances neutres ont de plus été caractérisées par chromatographie afin d'examiner les fractions pyrolytiques correspondant aux fractions biologiquement actives de la fumée de cigarettes. On a déterminé séparément pour pyrolysat de tabac reconstitué et de feuille les phénols, acides carboxyliques, les hydrocarbures aromatiques polynucléaires (PAH) et la nicotine. L'analyse des constituants de différentes fractions des pyrolysats indique de façon significative une teneur plus faible en phénols, PAH et nicotine dans les pyrolysats du tabac reconstitué et des côtes que dans ceux des feuilles.

\section{REFERENCES}

1. Wynder, E. L., and D. Hoffmann: JAMA 192 (1965) 88-94.

2. Dontenwill, W., H. Elmenhorst, H. P. Harke, G. Reckzeh, K. H. Weber, J. Misfeld and J. Timm: Z. Krebsforsch. 73 (1970) 265-314.

3. Halter, T. M., and T. I. Ito: J. Natl. Cancer Inst. 48 (1972) 1867-1878.

4. Chouroulinkov, I., P. Lazar, C. Izard, C. Libermann and M. Guérin: J. Natl. Cancer Inst. 46 (1969) $981-985$.

5. Hoffmann, D., and E. L. Wynder: J. Natl. Cancer Inst. $4^{8}$ (1972) $1855-1868$.
6. Atkinson, W. O.: Proceed. of the Tob. and Health Conf., Lexington, Ky., February 24-25, 1970, 28-33.

7. Klimisch, H. J.: Z. Lebensmitt.-Untersuch. 150 (1970) 93-99.

8. Müller, R., and P. Schlemmer: Ber. Inst. f. Tabakforsch. Dresden 19 (1972) 22-34.

9. Schlotzhauer, W. S., I. Schmeltz and L. C. Hickey: Tob. Sci. 11 (1967) 31-34.

10. Bock, F. G., A. P. Swain and R. L. Stedman: J. Natl. Cancer Inst. 44 (1970) $1305-1310$.

11. Schlotzhauer, W. S., O. T. Chortyk, H. Higman and 1. Schmeltz: Tob. Sci. 13 (1967) 153-155.

12. Schlotzhauer, W. S., E. B. Higman and I. Schmeltz: In "The chemistry of tobacco and tobacco smoke"; Plenum Publishing Corp., I. Schmeltz, ed., New York, 1972.

13. Darkis, F. R., L. A. Baisden, P. M. Gross and F. A. Wolf: Ind. Eng. Chem. 44 (1952) 297-301.

14. Muranaga, T., T. Tsugane and T. Kurosawa: Japan Monop. Corp. Cent. Res. Inst. Paper 107 (1965) 51-56.

15. Stedman, R. L.: Bull.-Coresta 1963-4, 11-23.

\section{Adknowledgements}

The technical assistance of Mr. Mark W. Ivey is gratefully adknowledged.

The authors' address:

Richard B. Russell Agricultural Research Center, Agricultural Research Service, United States Department of Agriculture, Athens, Georgia, jo604, USA. 